\title{
Innovative Research of Internal Accounting Information Control Systems under Network Environment
}

\author{
Lili Zhao ${ }^{1, a}$ \\ ${ }^{1}$ Qinhuangdao Institute of Technology, Qinhuangdao, hebei, China \\ a59682423@qq.com
}

Keywords: Internal control, Accounting, Information Systems, Network Environment.

\begin{abstract}
Establish an effective computerized accounting information system of internal control system in order to avoid a new computerized accounting information system risk is very necessary to the network environment. This paper intends to issue and risk control system under the network environment computerized accounting information system exists in-depth analysis, the network environment to explore preventive measures of risk and internal control system innovation computerized accounting information system.
\end{abstract}

\section{Introduction}

Affect the development of computerized accounting work is multifaceted. In the process of implementation of accounting, computerized accounting not only changed the way data is stored in the form of accounting and data processing procedures and methods to improve the quality of accounting work, and also changed the internal control and audit methods and techniques to promote accounting theory accounting techniques to further improve and is now in the process of continuous development of science and technology, computerization has been a trend of development of enterprise accounting, computerized accounting is the premise and foundation generated and accelerated accounting development field. [1].

\section{The Impact of computerization on corporate accounting work}

Accounting impact on corporate accounting work is multifaceted, whether in the form of data processing or data storage aspects corresponding changes in the application of computerized business accounting work has an important impact on improving the efficiency of accounting work (shown in Fig.1).

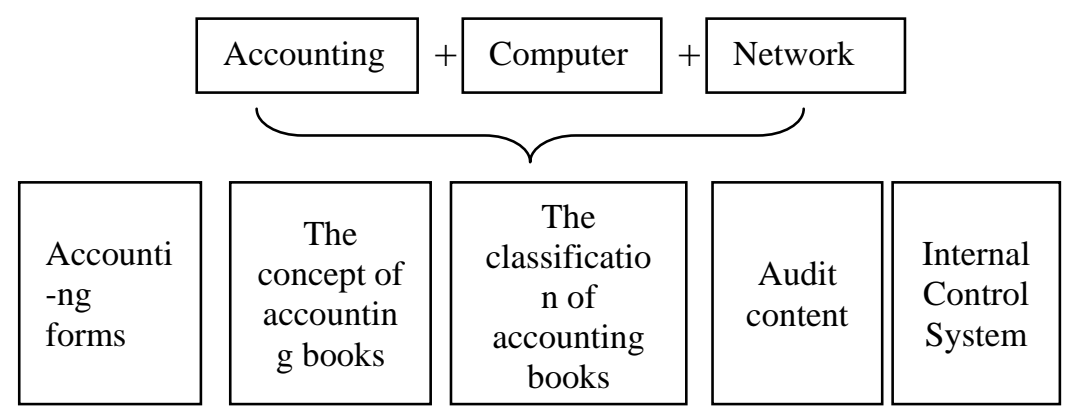

Fig.1 Impact of computerization on corporate accounting work

In the form of accounting changes. In the past, mainly to the content of accounting bookkeeping accounting documents of registration in accordance with the general ledger accounts to the journal and in a breakdown in the process of implementation of this manual way, computerized accounting applications to businesses, a significant change in the accounting bookkeeping, accounting methods [2].

Concept and classification changes of accounting books. The books accounting refers to accounting documents classified on the basis of economic business records account book account book of the nature and purpose can be divided into the time sequence for reference books and ledger books [2]. In the past, manual accounting books purely data stored in the new documents produced, 
the direction and amount of accounting data transcribed now, under the influence of computerization, has changed this mode.

Audit content changes. In the implementation of accounting work, either in the form of computerized or manual mode, you need to carry out its oversight function, but the difference is a change in the content of the audit of computerized systems in the accounting work of the content will be carried out by a computer program in accordance with treatment, but if there is an error within the system, the computer will only error in accordance with established procedures and methods of handling matters related to these errors in the accounting process of implementation, it is not easy to detect [3]. This is to some extent increase the risk and difficulty of corporate accounting and auditing work.

Internal control system changes. In manual form of accounting, the accounting staff on the basis of a different division of duties, organization of accounting, it can be a good run, but in the computerized accounting work, in addition to professional accounting staff, it also requires a corresponding system managers and operators, according to a new form of work in the past operation of corporate accounting manual operation of the internal control measures in the computerization mode has no longer necessary [3].

\section{Problems of internal accounting information system under the control of the network environment}

Continuous application of network information technology has changed the external environment and internal factors of Economy and management, although a competitive advantage to the enterprise [2]. With the changes in business processes, open systems, decentralized nature of information, sharing of data from the past to make the system a closed to an open centralized state, but it also brings opportunities for risk, the detail is shown in Fig.2.

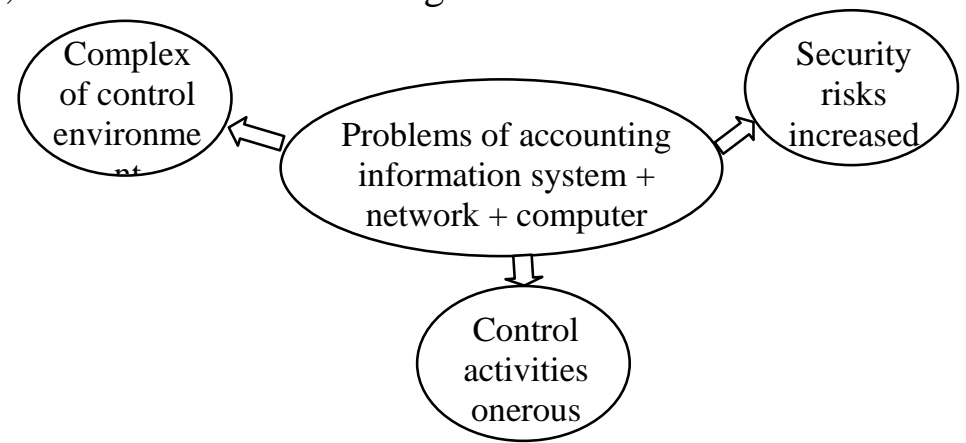

Fig.2 Problems of internal accounting information system under the control of the network environment

Control environment is complex. In the network environment as a result of the relevant management personnel can easily manage at any time to obtain the required information from the office computer through the network [4], making the internal management structure of the flat, so that the internal control structure is changed. The center became the action to guide the organization of the network economy from mechanical to organic style, and ultimately to the evolution of the virtual organization.

Increased security risks. Corporate oversight is done by people in the network environment [4], due to the openness and confidentiality, system programmers, system operators, systems analysts, network systems maintenance of financial information and other staff members within its competence the work set a certain password or password, but the system operator evil intents, unauthorized change passwords or passwords of others, is bound to cause confusion network systems management, giving the network environment accounting information at risk.

Control activities onerous. With the expansion of the scope of computer use, the use of computer fraud, corruption and other criminal activities has increased, such as data stored on a computer disk of the media can easily be tampered with, highly centralized database data, unauthorized persons possible through computer all data files and Web browsing, copying, forgery, destruction of business 
critical data, so that the computer has a lot of hidden crime and danger. Therefore, also increases network IT environment of internal control difficulty and complexity [4].

\section{Innovation Network Accounting information system of internal control system}

To avoid risks, the company's production and business activities require appropriate internal control systems of innovation as a guarantee, therefore, by means of a network of information technology, the use of information resources in a timely manner will be the capital market, product market supply and demand conditions, customer information, policies and regulations of the information collection and organize, conduct sensitivity analysis by multi-model simulation computer, timely regulatory operational risk, improve the investment decisions. It is shown in Fig.3.

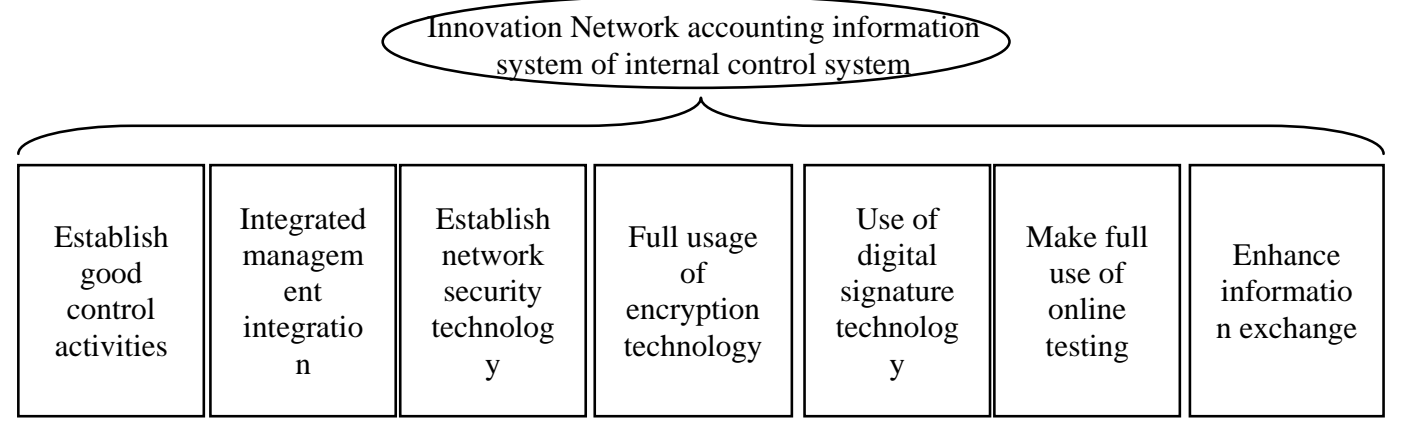

Fig. 3 Innovation Network Accounting information system of internal control system

Establish good control activities. Control activities are designed to enable the necessary action against the risk of business objectives cannot be reached and taken control activities should be considered and applied to all walks of life across the enterprise [5], with a variety of functions, including approval of such authorization, verification regulation, review business performance, a variety of activities to protect the security and segregation of duties and other assets.

Use of network information technology to achieve the integration of corporate finance and business management integration. Enterprises should be under the network environment by means of information for the completion of a coherent marketing business, financial processing and integration of business processes, build a real-time effective planning and budgeting systems, accounting and other management information process, reform the traditional business structure, improve operational efficiency, reduce costs, strengthen internal management of the normative basis [6].

Establish an effective network security technology. Into the anti-virus software on your computer, so that when the boot real-time control of the hard disk for virus detection, to detect and kill the virus; regular backups of data and files; do not open and read e-mail from unknown sources [5]. To virus control, protection and centralized data management integration, centralized control, hierarchical management model, the establishment of sub-systems or sub-group of the total center of anti-virus systems, unified upgrade update the virus scan engine and signatures, the virus system monitoring in order to establish a good virus protection system.

The use of encryption and digital signature technology to solve the risk of digitized original documents brought. In order to protect the accounting data is not stolen or modify others in the transfer process, the need for data encryption, so that even if someone stole the data, but there is no key to open, so it cannot be reduced to plain text, and to protect the security of data [6].

Make full use of online testing software applications and timely solutions to their own problems. In the software process, the developers of the enterprise system can be carried out by a network of regular online testing, test the integrity of the entire system, and to deal with fault tolerance, anti-jamming capability and resilience to incidents of illegal data and system ability to recover after damage suffered to focus on testing, found a quantity problem, promptly notify the enterprise and online upgrade [5], the existence of time control software problem in the shortest possible, improve the security of the system.

Enhance information exchange and communication. Enterprises in their management and process control, the need to press for some form of identification and obtain information from internal 
and external, and communicate within the organization, so that employees get clear information about their control responsibilities to fulfill its responsibilities [6].

\section{Summary}

This paper introduces the concept of computerized study the functions and features of the internal control of computerized accounting systems, a detailed analysis of the computerized accounting information system problems and possible risks, on the basis of the network environment computerized accounting information systems and internal control processes, computerized accounting system under the network environment of internal control carried out innovative research, designed to help companies improve risk awareness while building computerized accounting system, carefully formulate internal control system, the letter implement appropriate control measures in order to ensure maximum quality of accounting information.

\section{References}

[1] Y. Li, New SME accounting implementation issues and ways, Accounting Communications,vol.10 , pp. 25-26, 2012. (In Chinese)

[2] M. Zhang, Computerized accounting in corporate financial management, Chinese township enterprises accounting, vol.13 , pp. 56-57, 2011. (In Chinese)

[3] $\mathrm{P}$. Wu, Talk computerized accounting for the impact of the accounting work and improve the quality of accountants, Shenzhen Polytechnic College,vol.9 ,pp. 45-49, 2013. (In Chinese)

[4] S. Li, Internal Environmental Accounting Research on Building Enterprise, Accounting System of Shenyang Normal University, vol.10 , pp.25, 2013. (In Chinese)

[5] Y.M. Zhang, IT environmental accounting information systems, Computerized Accounting China, vol.1, pp. 20-21, 2012. (In Chinese)

[6] Y.B. Xu, Internet-based accounting information systems control, Accounting Research, vol.8,pp. 36-39, 2010. (In Chinese) 